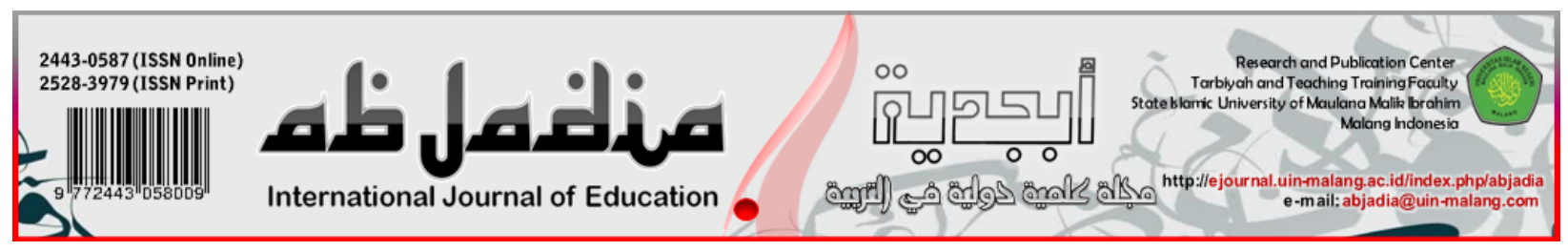

\title{
REVEALING EFL STUDENTS' RESPONSES ON THE USE OF SOCRATIVE IN READING ACTIVITY
}

\author{
Dewi Nur Suci \\ IAIN Kediri, Indonesia
}

\begin{abstract}
Article History:
Received : 20-11-2020

Revised : 15-12-2020

Accepted : 19-12-2020

Published : 31-12-2020
\end{abstract}

\section{Keywords:}

Reading Activity, Socrative, Students

Responses

*Correspondence Address:

dewinursuci@iainkediri.ac.id

\begin{abstract}
Industrial Revolution (IR) 4.0 has influenced practice of English Foreign Language (EFL) instruction. One of which is through the deployment of Socrative as the technology integration to enhance the students' skills of listening, reading, writing and speaking. This paper was aimed at elaborating the use of Socrative in English academic reading classrooms done by students in university level. The students' responses on their experiences when utilizing this application were revealed. The results exemplified that students used Socrative for reading activities. By collecting the students' opinions on Socrative via a survey, it was found out that the students could enrich their vocabulary because they employed a reading strategy that should be implemented by them, such as noting difficult word(s), and looking for the meaning in dictionary. In another side, the students argued that this online application had a lack of aspect in a reading course. Further, recommendations on the practice of Socrative in EFL classroom are discussed
\end{abstract}

\section{(C) Introduction}

The utility of technology for information accessibility and credibility in reading skill that is able to optimally initiate a new model of educational implementation based on competencies where the students are highly directed to acquire autonomy and adequate learning process (Arifani \& Rosyid, 2016; Stearns, 2012; Taj, Ali, Sipra, \& Ahmad, 2017; Zarzycka-Piskorz, 2016). Due to the importance of technology integration in tertiary level of EFL classrooms, this research is aimed at developing the materials for evaluating students' academic reading comprehension, promoting the use of Socrative application as an effective assessment and feedback application, and investigating both the students' and the teachers' preparedness, behavior and perception on the technology integration.

Materials for reading evaluation are necessary to develop the students' output. Krashen's theory (1985) in (̌̌epová, 2004) states that the more comprehensible input the greater the L2 proficiency and lack of comprehensible input can cause a language acquisition delay. It is argued that the optimal input must be comprehensible, interesting and relevant, not grammatically sequenced, sufficient in quantity, and a little bit beyond the students' level of comprehension, known as i + 1 (Abukhattala, 2012; Krashen, 2008; 
Latifi, Ketabi, \& Mohammadi, 2013). In addition, Ramos (2015) examines that reading as a receptive skill is beneficial to gain students' incidental vocabulary in which L2 learners develop much of their vocabulary through exposure to words in informative contexts. In broader context of reading style, (Krashen, 2008) agrees that a substantial amount of research strongly suggests that reading is the way we learn to write, particularly acquiring the reading style and the special language of reading.

Regarding to the urgency of reading evaluating materials in enriching the student's language acquisition, the teachers of EFL classroom need to selectively integrate the use of technology. Teachers in higher education who are more challenged in today's education to keep up with the rapid growth of technology can function Socrative, one of online applications that is useful for measuring student's English skills (Yoon, 2017). Fakhr \& Khalil (2016) argue that teachers prefer using Socrative for its effectiveness in checking the students' answers and facilitating teachers to monitor students' progress easily in large classrooms because as the this app can display quizzes results either per class, per student or per question. Other research also find it useful for student's response contributed to increasing the students' level of engagement, promoted their critical thinking, and stimulated their collaboration (Fakhr \& Khalil, 2016; Hadiri, 2015; Dakka, 2015).

Some researchers have done research by using Socrative. Yoon (2017) investigating students' perspectives on Socrative in 4-skills integrated EFL classes find out that students have positive perspectives on using Socrative to elevate their participation in sharing opinions and interacting with teachers. Besides, the students prefer to employ that application to check comprehension and to collect responses for speaking activities. However, this research is different from the current research that is trying to focus on academic reading comprehension. Additionally, Dakka (2015) investigating the student engagement in higher education for level 5 engineering students reveal that $53 \%$ of the students improved their performance while 23\% neither improved nor underperformed. Differently, this current research is focused on students of English department in academic reading course. Another research by Ohashi (2015) examines that Socrative can be useful for online student response system (OSRS) and assist them brainstorm in reading plan. In contrast, this current research centers on receptive skill, particularly reading comprehension.

Considering the importance of Socrative in EFL classroom for its efficiency, effectiveness, and attractiveness, this research concerning on how to use Socrative in academic reading and how the students' response towards this application. This research provided students in English Education Department with English academic reading materials that are relevant to the $21^{\text {st }}$ by promoting the autonomous learning model (ALM). Socrative is purposively selected media that can widely represent the needs of students to be autonomous learners. This applications can strengthen the students' responsibility to improve their academic reading skills and critical thinking because the 
students can explore this applications easily. However, the issue on using SRS has been debatable issue in teaching and learning process. Thus, this study attempts to identify how the EFL students' responses on the use of Socrative in reading classroom.

\section{$\mathbb{Q} \mathbb{d}$ Theoretical Support}

\section{English Academic Reading}

Academic English is dynamic in the sense that it is constantly evolving in the shaping of meaning in educational contexts (Scarcella, 2009). Deficiencies in academic English are evident among English learners (ELs) by any measure. Academic reading often requires you to engage actively and critically think about the information taken. Reading activity varies in any purposes and needs strategy to interpret and use information. Instead of passively reading information, reading scholarly sources of information encourages readers to ask any questions about what they are reading, and encourages them to link to existing knowledge. Individuals would be subjected to text documents as a university student. Some of them will contain unfamiliar terminology or complex concepts. However as readers develop their academic skills, it will be easier to understand academic material.

Reading strategies are indeed a helpful way to take advantage of information and manage complex and long texts. There have been some practicable procedures for students in EFL classrooms, such as breaking down large chunks of writing into manageable components, taking notes as they read, paused to absorb the information you read (rehearse it in your mind), taking regular breaks when reading longer pieces of information, and having a dictionary and pen to underline unfamiliar words. Besides determining the main idea is important rather than the individual words. The students can brainstorm on what they are reading and draw on support to gain understanding of the context (lecturer / tutor notes, reviews of the text, discussion forums).

Scholarly reading of academic papers is published in distinct branches of science papers, such as case studies, survey reports, theoretical papers and review papers. Day (1989) and Bach (2013) state that the IMRAD document design (Introduction-MethodsResults-Discussion) can be advised mostly as successful trajectory based on the type of paper. The format of the IMRAD is based on the four sections of the article which are shown (1) Introduction to demonstrate what the problem was studied, (2) Method

portraying how the issue was researched. (3) Result to demonstrate what the findings of the study are (4) Discussion to highlight what the findings mean by providing IMRAD format to beginner authors. This IMRAD format tends to be used by Science and Scopus Web to organize journal articles. 


\section{Online Learning Application}

Technology keeps advancing rapidly and it becomes an integral part of our daily activities. We use it every day to fulfill many of our basic needs, such as completing assignments, socializing, or simply having fun by playing games. The massive use of ICTs also has contributed to the many new possibilities of using technology in learning and teaching English. As educators, we are looking for ways how to customize and relate the students' enthusiastic in the using of ICTs to the educational context. Moreover, the ways of teaching which can engage and motivate the students to actively participate in learning; listening, speaking, reading, and writing. Several language learning tools can be accessed anywhere and at any time from Internet which can also be used at various levels in various subject areas. They are Socrative, Quizlet, Mentimeter, Grammarly, Answer the Public, and others. However, Socrative is relevant for reading activity.

Socrative is one of learning tools that is web-page and was firstly created for students' responses formative system (Awedh, Mueen \& Manzoor, 2014). Then, it is widely used by any teachers to design questions of a multiple-choice (MCQ), true/false, or open-ended short questions. Therefore, this tool provides an ease for the teachers to engage students in classroom activities. By using any of the available personal mobile technological tools such as smart phones, laptops, or tablets, the teachers and students can use it with internet connection. The teachers can share the room to do the exercise, while the students can access the exercise by typing the room code.

\section{[Q] Method}

Under survey design, this study distributed questionnaire to fifty four students of English Education department in a state Islamic university who were in the fourth semester. The distribution of questionnaire via Google form was done in the end of semester before the spread of COVID-19. The details of using Socrative are presented in Figure 1 and 2. The questionnaire that was adapted from Dervan (2014) comprised questions that elaborated the students' responses on the utility of Socrative in reading classroom. Socrative was used for the evaluative materials for reading that were based on the texts from academic articles. The materials consisted of multiple choice and short answer. Because there was no time limit in reading by using Socrative for free access, the teacher set the time herself for about thrity to fourty minutes. The use of Socrative was usually done after the students learned a certain topic on reading based on the syllabus or prior to reading activity. During their reading, the students were able to jot down any information in the online text. In the end of reading activity, the students discussed the results together. Here, they also had known their results since the setting of Socrative was providing the final scores. The result of the questionnaire was interpreted descriptively to understand the use of Socrative. 


\section{$8 \$ 8 B$ HOW TO USE SOCRATIVE}

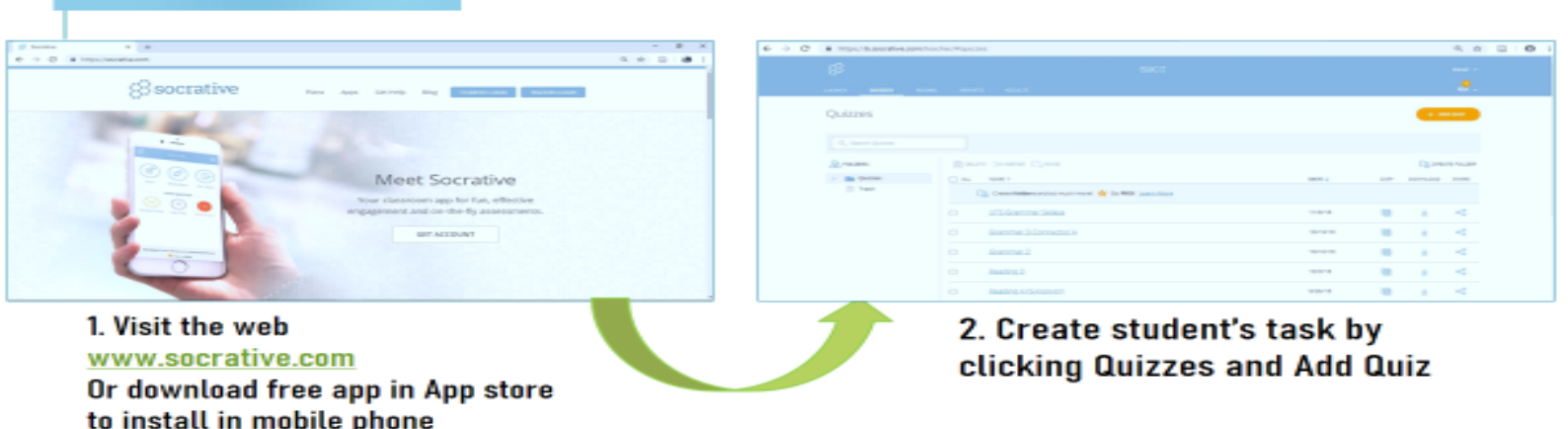

Figure 1. Step 1 to use Socrative

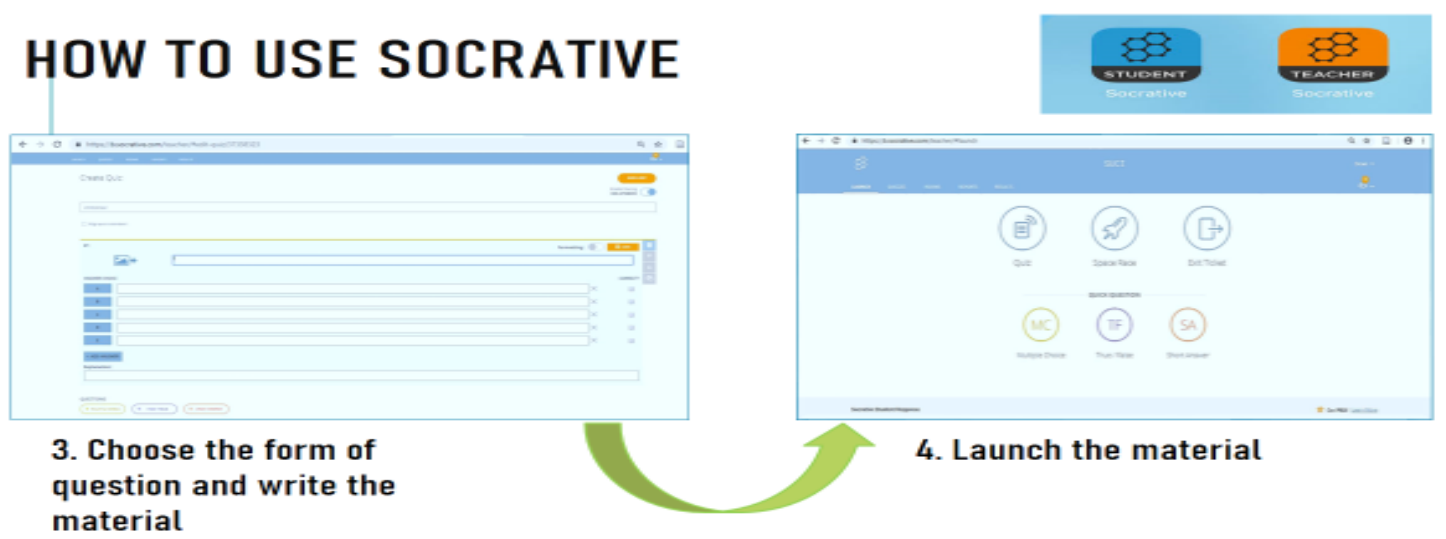

Figure 2. Step 2 to use Socrative

\section{Result}

\section{Socrative is effective for academic reading course.}

Based on the result of descriptive statistics, it is found out that 22 students agree that Socrative is effective for academic reading course and 7 students strongly agree that this application can be effectively used for academic reading course. In contrast, 2 students do not agree that this application is effective and 23 students show neutrality on using this application. Itindicates that Socrative can be used in the classroom, although there is a certain consideration in using it because a slight comparison between the students who agreed and disagree with.

\section{Socrative is easy to access in academic reading.}

However, accessibility of Socrative remains a challenge for the students. 25 students experience bad internet connection when they are directed to access this application, while 29 students disagree that Socrative is difficult to access. It is that because not all of the students have their private data account to connect with internet. Most of them actually use Wi-Fi at campus which has low bandwidth. It implies that the 
university should increase its internet bandwidth so that the students can access the internet easily.

\section{Socrative is fun in showing new or difficult vocabulary.}

42 students agree that Socrative assists them to learn new vocabulary, 8 students show their neutrality and 4 students disagree with the use of Socrative to cope with vocabulary difficulty. It is that because during the reading process, the students are familiarized with words which have related meanings. In addition, the students are encouraged to jot down what new words or difficult vocabulary they are reading. In the end of their reading by using Socrative, the students share the meaning of new and difficult words with their classmates.

\section{Socrative can support students to understand the academic texts}

Because academic reading is one of subjects that has to be mastered by undergraduate students, it is recommended for the students to familiarize with academic text. Because the materials that are uploaded in Socrfative are about academic reading, the students agree that Socrative can assist them learn academic text. The texts that are provided are in the form of abstracts of an article, the texts in IELTS book, the paragraphs of introduction or other short paragraphs. Accordingly, the studentslearn academic texts in Socrative. In this kind of activity, 47 students responded that they agree with the function of Socrative, while 7 students regard this application does not facilitate them to read the academic texts during semester.

\section{Socrative can help students to understand main ideas and supporting ideas in academic texts}

Reading comprehension comprises how to understand main ideas and supporting ideas in academic texts. Accordingly, the students can learn it in Socrative. Here, 44 students agree that Socrative can help them understand main ideas and supporting ideas. It is that because they are always directed to do the reading task in Socrative. However, it is found out that 10 students might find difficulty in understanding the main and supporting ideas in academic texts because of low internet access. In fact, some are not because they have easy access to the internet. Besides, the questions are various in the form of multiple choice, true false, and short essay. In so doing, the students can understand main ideas and supporting ideas in academic texts easily.

\section{Socrative can be easily accessed through laptop, computer and mobile phone}

Because Socative is an online learning application, it can be accessed through the use of any gadget such as laptop, computer and mobile phone. This promotes userfriendliness for the students because the application has easy menu to use. The students do not need to have an account. They just need to log in by entering the room name that has been shared by the teacher. Then, they can enter their name in Socrative. In so doing, the students can directly access the Socrative and do the reading activity. Simply said, Socrative is an online application that is easy to use. Therefore, 39 students agree that 
Socrative is easily accessed through their gadgets, while 15 students disagree with this statement.

\section{Socrative can motivate the students to learn academic texts}

Based on the questionnaire, 34 students agree and 30 disagree with this statement. It can be influenced by the internet connection they had and the first experience in using this online learning application. This indicates that the internet connection can influence the student's interest in accessing the application.

\section{Socrative can motivate the students to improve their achievement in academic reading}

25 students argue that Socrative can enhance their achievement. In fact, 29 students argue differently that Socrative has no any influence on their motivation. When asked in forum group discussion, it is found out that some students who obtain high scores showed their agreement, while those who got low scores expressed their disagreement. Thus, it implies that high and low scores became the indication on the disagreement of the statement that Socrative can motivate them in reading activities.

\section{Socrative contains quiz and other interesting features to study}

32 students argue that Socrative contains quiz and other interesting features to study. On the other hand, 25 students argue differently that Socrative is a usual application. Similar to the opinion of Socrative and the students' motivation, the students' arguemnts are in line with their scores. When asked in forum group discussion, it is found out that some students who obtain high scores showed their agreement, while those who got low scores expressed their disagreement.

\section{inis Discussion}

Socrative is an online assessment and student response tool that provides opportunities to increase student engagement in the classroom. The students' responses to the survey of this study indicated that Socrative-based activities were a useful interactive learning approach during lectures. The positive views were portrayed by the students related to their engagement within a reading session with peers and with their lecturer when the immediate feedback was provided. They argued that this type of activity was more encouraging to their participation in the learning process. Students were also supportive to the utilization of Socrative in the classroom because it provided the percentage of class which show who correctly answered a question. Relatedly, it gave an idea about the class performance as a whole. Therefore, Socrcative shares its feasibility for the students and the teachers in language classrooms.

For ease of use, Socrative is accessible for the students, except its internet connection. This study has shown that most of students argue that Socrative is affordable. This is in line with the Dervan (2014) study which found that Socrative is better than Clicker's application. It is because Clickers needs operating systems going to run on a PC 
that should be linked to the overhead projector system. However, the students that used Clickers tended to tell that they got lack of privacy since their score can be seen by other students. Therefore, Socrative due to its cloud based system promotes its effectiveness and efficiency for its use.

The result of this study also showed the students received high and lowe scores in reading activities. The students' experiences on the use of Socrative were given as weekly assignments during the period of educational evaluation in academic reading. Within the framework of this experience, the students' responses were examined also in the results of the final exam. Some students who were familiarized themselves by noting the difficult vocabulary and expressions during the reading activity by Socrative perceived positive usefulness of Socrative. It was shown by their responses on how it can impact on their reading skill. Overall, the results indicate that the use of this mobile technology of Socrative has shown a progressive effect on the students' reading activities in English department in higher education.

In addition, implications of SRS systems reading activity were determined by a variety of factors, such as student mastery in the subject matter, the frequent use of devices and internet connection. Even then, one of the most important elements of learning with this online tool is the attitude of students towards their use (Dervan, 2014). In this study, there was a relationship between the responses' attitude of the students towards the use of Socrative in weekly assessment and the results achieved in the final exam. It is seen from the positive attitude of the students about the use of Socrative. Their understanding on the text and the way they read grew better their academic performance.

Reflected to the weekly activities, the students can explore the quiz in Socrative more than once. Accordingly, the students had their opportunity to meticulously read the quiz. It is in accordance with what has been suggested by a number of previous researchers. In US context, Dervan (2014) uncovered that Socrative activities contributed to increasing the students' reading comprehension. The students were able to go up their level of engagement, promote their critical thinking, and stimulate their collaboration. Under survey study, Dervan (2014) scrutinized that first year Sports Management students actively participating in the Contemporary Sports Management Module at the Institute of Technology, Blanchardstown (ITB) showed high level of engagement during group discussions and felt very interesting to do quiz Socrative by using mobile. Therefore, Socrative is useful for reading activities either for academic and non-academic texts with various activities integrated.

\section{词 Conclusion}

This study has shown that students show their agreement and disagreement on Socrative use as Student Response System (SRS) during lectures in reading classrooms. 
This is not only reliable to use, but also easy to operate. The most important aspect is most of the students in this study argued that the use of Socrative as weekly assessments that can be done in brainstorming or reinforcement stages of learning had helped them understand course concepts. Because it was their first experience in using Socrative in a face-to-face meeting, the students found some difficulties in their first experiences. Besides, the internet connection availability should be a concern because most of students complained on the availability of the internet connection.

For further research that are interested in the same topic, they can analyze the use of Socrative for other subjects other than English. Another variable which characterizes the students, such as gender, students' language proficiency level, social socio economic status, or perceived usefulness of Socrative can be investigated. This can be done to avoid bias on the students' scores. It is because most of the students in this study who obtained low scores disagreed that Socrative helped them in reading activity and boosted their motivation. On the other hand, the students who increased their score gradually or sharply tended to say that Socrative were able to support their reading comprehension and motivation. Therefore, further investigations can be done.

\section{Acknowledgment}

We would like to thank you for LP2M IAIN Kediri that funded the research.

\section{Bibliography}

Abukhattala, I. (2012). Krashen's five proposals on language learning: Are they valid in Libyan EFL classes. English Language Teaching, 6(1), 128-131. https://doi.org/10.5539/elt.v6n1p128.

Arifani, Y., \& Rosyid, H. (2016). Integrating reading and technology: The development of Paman pintermu. English Language Teaching, 9(11), 13-28. https://doi.org/10.5539/elt.v9n11p13.

Awedh, M., Mueen, A., Zafar, B., \& Manzoor, U. (2014). Using Socrative and smartphones for the support of collaborative learning. International Journal on Integrating Technology in Education, 3(4), 17-24. https:/ / doi.org/10.5121/ijite.2014.3402

Bach, M. P. (2013). How to write and publish a paper in a journal indexed in Web of Science: A closer look to Eastern European economics, business and management journals. Working Paper Series-Faculty of Economics and Business, 13(5): 1-12.

Day, R.A. (1998). How to write and publish a scientific paper. Oryx Press: Phoenix

Dervan, P. (2014). Enhancing in-class student engagement using Socrative (an Online Student Response System): A Report., AISHE-J, 6(3), 1801-18013. 
Fakhr, N., \& Khalil, N. (2016). Large classroom predicament resolved: Tackk and Socrative in the flipped approach. In ICT for language learning (Vol. 9th edition, pp. 52-55). Florence-Italy: Libreria Universitaria Edizioni.

Hadiri, Y. (2015). Click it to check it: An instructional design module to assist university faculty in using Socrative as a smart student response system for student assessment. PowerPoint presented at the Technology Colleges, and Community Worldwide online conference, the department of learning design and technology (LTEC). Retrieved from

https:/ / scholarspace.manoa.hawaii.edu/bitstream/10125/35948/TCC\%20Final\% 2 0Presentation\%20Slides\%205-8-2015.pdf

Helmers, J. R. (2017). Using technology and collaboration to support reading comprehension (Master's thesis). Northwestern College, Orange City. Retrieved from http:/ / nwcommons.nwciowa.edu/education_masters/38/

Krashen, S. (2008). We learn to write by reading, but writing can make you smarter. Ilha Do Desterro A Journal of English Language, Literatures in English and Cultural Studies, 0. https://doi.org/10.5007/2175-8026.2003n44p67

Latifi, M., Ketabi, S., \& Mohammadi, E. (2013). The comprehension hypothesis today: An interview with Stephen Krashen. Electronic Journal of Foreign Language Teaching, 10(2), 221-233.

M Dakka, S. (2015). Using Socrative to enhance in-class student engagement and collaboration. International Journal on Integrating Technology in Education, 4(3), 13-19. https://doi.org/10.5121/ijite.2015.4302

Ohashi, L. (2015). Enhancing EFL writing courses with the online student response system Socrative, 19(1), 135-145.

Řepová, K. (2004). Testing Krashen's input hypothesis: A case study in a male Czech adult acquiring English (Thesis). Masaryk University, Brno.

Stearns, S. C. (2012). Integration of technology into the classroom: Effects on reading comprehension (Master Thesis). Southern Illinois University, Carbondale. Retrieved from http:/ / opensiuc.lib.siu.edu/gs_rp/248

Taj, I., Ali, F., Sipra, M., \& Ahmad, W. (2017). Effect of technology enhanced language learning on EFL reading comprehension at tertiary level. Arab World English Journal, 8(1), 108-129. https://doi.org/10.24093/awej/vol8no1.9

Yoon, S. Y. (2017). Using learner response systems in EFL classrooms: Students' perspectives and experience. Multimedia-Assisted Language Learning, 20(2), 36-58. https://doi.org/doi:10. 15702/mall.2017.20.2.36

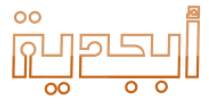

